\title{
The Investigation of Effect of Customer Orientation and Staff Service-Oriented on Quality of Service, Customer Satisfaction and Loyalty in Hyperstar Stores
}

\author{
Nazanin Jarideh \\ MSc Student of Business Management, International Business, Islamic Azad University, Qazvin Branch, Qazvin, Iran
}

\begin{abstract}
Customers during judge the quality of a service often consider on the behavior of employees. Therefore customer orientation of employees is an important factor for the success of an organization. It is also mentioned in the marketing theories; organizations that focused its activities on customer needs (customer-oriented behavior) have better performance than other organizations. In aim of study is investigated the impact of customer needs and staff service-oriented on quality of service, customer satisfaction and loyalty in Hyperstar stores. This study from the goal is applied and from the nature is descriptive- survey. To test the hypotheses, analysis track performed by LISREL software. The results showed that customer-oriented of staff and their service-oriented had positive correlation with and perceived service quality of customer. Perceived service quality had positive correlation with customer satisfaction.
\end{abstract}

Keywords: customer orientation, service-oriented, the quality of service, customer satisfaction and loyalty

\section{Introduction}

Customers are the material and intellectual capital of organizations. The survival and success of any organization absolutely depends on the attitude and performance of the organization to the customers. Hence plan for a deep understanding and immediate future needs of our customers and meet these needs are organizational policies. Customer orientation, increasing competition, rapid technological changes, globalization and new concepts that are so on, strongly impressed the world today and it have a very distinct from the early universe so that old ideas cannot compete in the new world or even the continued survival. High speed change challenged most of the organizations; the challenge that the key to survival in it depends only on the optimal use of opportunities.

In today's competitive environment it is essential that directors of institutions develop their ability to determine the most important factors in choosing a product or service to market segments that tend to attract and serve to it. Managers of institutions must recognize what is important to their customers in their target market and how to compare the strengths of their institution with the rivals' strengths. The main purpose is a marketer beyond the sale and usually the ultimate goal is create a lasting commitment between a specific brand and a specific customer group that this is make a commitment for make a process including the introduction, familiarity, preference a brand, and finally create loyalty (Sanayeii et al., 2006).

Many researchers have emphasized the key role of staff that related to customer or front-line employees in organizational success. Results and positive outcomes for organizations such as customer satisfaction, loyalty, and positive word -of mouth, significantly can take effect from personal interaction between staff service provider and customer. As well as, strategy goals of relationship marketing is retaining valuable customer (Macintosh et al., 2007). During the judge the quality of a service, customers consider the behavior of staff who is the service provider. Therefore, customer orientation of employees is an important factor for the success of an organization. It is also mentioned in the marketing theories organizations that focused its activities on customer needs (customer-oriented behavior), have better performance compared to other (Hennig-Thurau, 2004).

The studies conducted so far in the marketing literature associated with the customer-oriented, that sellers must have tendency to attract customer satisfaction, not merely to sell their products to them. Research in this field emphasized on the role and importance of meeting the needs of customers in the sales process. Customer orientation is the values that the seller is trying to help the customer, to adopt purchasing decisions to help to meet customer needs. Customer orientation has contributed to creating value for customers and market-oriented and customer-oriented companies attach top priority to maintaining value for customers (Liang et al., 2010).

Today in the process of sales and service, service workers effectively been debated. In a competitive environment, having efficient human resources has an important role in gaining competitive advantage. In this regard, the customer orientation considered as one of the interesting topics of marketing that looks to meet the needs of customers. The role of customer orientation has been much attention in recent years outside the country but in a country not pay much attention to it. Organizations to enhance the quality of their services are forced to pay more attention to our customers.

Also with increasing competition among organizations, the fact is undeniable that the market power affected by the customers. Customers today have more opportunities to compare goods and services and management needs and 


\section{International Journal of Science and Research (IJSR) \\ ISSN (Online): 2319-7064 \\ Index Copernicus Value (2013): 6.14 | Impact Factor (2014): 5.611}

demands of them are more complex and specific. Customers are determining of importance. Understanding customer needs is the most basic needs for survival in today's organizations. The most important factors in creating and retaining customers are the main factors affecting on customer behavior and their decisions. Of course, most companies have found that their survival depends on having satisfied and loyal customers and this is the key point in continuing organizational activity. One of the objectives of each organizational unit to survive and compete in the global village, is increase satisfaction and customer retention, therefore this issue can affect all organizations' strategies. One of the best ways to create and maintain customer satisfaction is customer orientation of organization staff. Customer orientation through the creation of good sense and happiness in customers cause the fulfillment of their expectations and thus retention the customers with organization. Therefore, research that examines the role of customer orientation has of particular importance.

According to previous research, customer orientation and service quality are important factors in building customer satisfaction and loyalty. Positive attitude to providing service to customers is not included in most prior research and very few studies have investigated the role of the customer orientation and service orientation. In this article we have tried to using the model and conceptual framework paid to the effect of customer orientation and serviceoriented of employees on service quality, customer satisfaction and loyalty of Hyperstar store.

\section{Theoretical Background}

Customer orientation is sufficient knowledge of buyers and target customers in order to be able to create superior value for them constantly. In other definition the customer orientation is set of a belief that puts customer interests in primarily. Customer orientation is trend to help customers in order to evaluate their correct needs and the decision to appropriate buy by them, providing services that meet the needs of customers, and avoid high-pressure sales tactics (Lee et al 2001). Customer orientation is the amount that employee behavior in individual interactions with customers, meet the needs of clients (Hennig-Thurau, 2004).

Broun and et al, (2002) have proposed two dimensions for customer orientation 1. Needs, 2. Enjoyement. Dimensions of needs associated with employee beliefs about their ability to meet customers' needs. Dimensions of enjoyement associated with the values that employees are able to earn the pleasure of interacting and serving to their customers. This view allows that this issue be raised the customer orientation of staff not only meet the needs of its customers but also for personal has pleasure of serving the customer (Lee et al 2001).

\section{Quality of service}

Today, people live in an environment that is increasingly moving towards a service-based economy. Today service is not a small part of the economy, but also is considered as the heart of value creation in the economy. Services is not limited to banking services, postage, insurance, health, and education but also often we buy products include the service. In fact, the whole range of goods for a competitive edge relies on service-based activities. Today, a car buyer buy a comprehensive package of benefits and services not only buys a car. Even commodities such as TV and washing machine usually associated with services such as delivery, financing, insurance and repair (Seyed Javadien Keymasi, 2010).

\section{Customer satisfaction}

Customer satisfaction is the customer's agreeable feeling as a result of his perception of fits the product or services with his expectations arise. Satisfaction is a positive emotion, that every person is created after using the product or service. If the goods and services received by the customer, meet her/him expectations create a sense of satisfaction in her/him. If the level of service and product be higher than expect of customer, will lead to his dissatisfaction (Abdollahian and Frozandeh, 2011).

Customer satisfaction in three ways leads to increase revenue and profit. Repeat customer purchases, buy new products and the purchase of goods by customers, has been in the forefront of marketing suppliers programs. Today, no supply manufacturer thinks to once sell to the customer. The important thing is that in case of customer dissatisfaction, all mechanisms acted in the opposite direction and reduces revenue and profit to supplier. Studies show that dissatisfied customers to transfer their feelings to others are more active and more successful (Abdollahian and Frozandeh, 2011).

\section{Customer loyalty}

Loyalty is a strong deep commitment to stable repurchase and consistent a product or preferred service in the future, while there are competitors marketing efforts to shift customer usage to another product or service. Fidelity can be achieved through, from more favorable attitude toward a company or a trademark in comparison with other companies and brands and repeat purchase behavior. Maintain a deep commitment to the customer to re-purchase or re-election a product or services from a brand or a company and do it continually in the future considered ad loyalty. Of course, by accepting the condition that influence the position and marketing efforts, potentially can lead to changes in customer behavior (Oliver, 1997)

Usually brand loyalty related to repeat purchases of clients. However, the repurchase may be only reflects the immediate satisfaction from their customers. Thus the concept of loyalty, both in attitude and behavior loyalty has been developed. Behavioral loyalty means that customers will buy again from the same brand; it appears that attitudinal loyalty is more durable than behavioral loyalty and reflects the preferences of the clients' commitment and when the unique value from a brand can be seen. Customer loyalty is the ultimate goal of company that has a product with a specific brand. Brand loyalty defined as priorities of a particular branded product on a shelf by the customer. Customers have found that their favorite brand provide them plan and healthy composition of the product and with a level of quality at affordable prices. The customer's perception is the basis for new purchases repeat (Javanmard and Soltanzadeh, 2010). 


\section{International Journal of Science and Research (IJSR) \\ ISSN (Online): 2319-7064 \\ Index Copernicus Value (2013): 6.14 | Impact Factor (2014): 5.611}

At the beginning customers, for the test, purchase products with the brand special, and after satisfaction tends to repeat the purchase and continue same trademark or brand, because it familiar and safe product. Brand loyalty is thinking such; to give more money to one brand over other brands tend and recommend brands to others (Javanmard and Soltanzadeh, 2010).

\section{Conceptual Model}

According to previous research, customer orientation and service quality is an important factor in building customer satisfaction and loyalty. Positive attitude to providing service to clients (service-oriented) are not included in most prior research and very few studies have addressed the role of the customer orientation and service orientation. In this study, we tried to select a model that can addressees both impact customer orientation and service-oriented have considered. Conceptual model or framework based on the model of Jayawardhena and Farrell (2011) and is shown in Figure 2-10. This model examines the impact of customer orientation and service-oriented of employees on service quality, satisfaction and loyalty of customers.

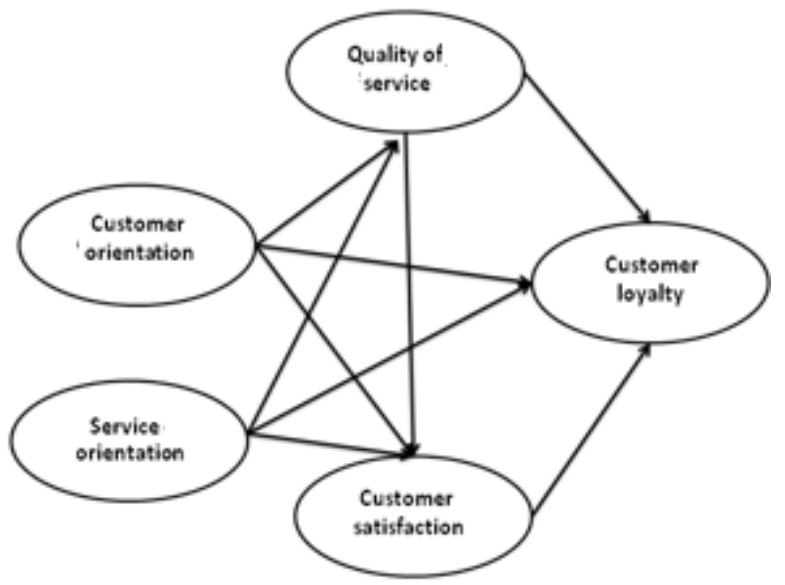

Figure 1: Conceptual model that used in this study (Jayawardhena and Farrell 2011).

\section{Hypotheses}

1) The customer orientation of employees positively affect on their service-oriented.

2) The customer orientation of employees positively affects the quality of service perceived by the customer.

3) The customer orientation of employees positively impact on customer satisfaction.

4) The customer orientation of employees positively affects customer loyalty.

5) Service-oriented of employees positively influence the quality of service perceived by customers.

6) Service-oriented of employees has a positive impact on customer satisfaction.

7) Service-oriented of employees positively affect customer loyalty.

8) Quality of service that perceived, positively impact on customer satisfaction.

9) Quality of service perceived positively affects customer loyalty.
10) Customer satisfaction has a positive impact on customer loyalty

\section{Methodology}

This study from the goal is applied and from the nature is descriptive- survey. In this research for data gathering, theoretical section from library method is used and in the executive branch a survival method used by a questionnaire. Statistical population also includes all customers in Hyperstar stores in Tehran, Iran that have at least than one shopping experience of these stores. Given that the number of statistical population in this study is unlimited. Therefore samples number was analyzed using Morgan table and considered 384. In this study available non-random was used for sampling. In this way the questionnaire by visiting the customer of Hyperstar stores in Tehran distributed, then collected. Of the 450 distributed questionnaires, 413 were returned (rate of Return of 92\%) and 384 of the most complete was analysis. The survey questionnaire, based on standard questionnaires Jaya Jayawardhena and Farrell (2011) was designed.

\section{Results}

Table 1: Calculation of direct and indirect effects and impacts of all independent and dependent variables

\begin{tabular}{|c|c|c|c|c|}
\hline $\begin{array}{c}\text { Independent } \\
\text { Variable }\end{array}$ & Dependent Variable & $\begin{array}{l}\text { Direct } \\
\text { effect }\end{array}$ & $\begin{array}{c}\text { Indirect } \\
\text { effects }\end{array}$ & $\begin{array}{l}\text { Total } \\
\text { effects }\end{array}$ \\
\hline \multirow{4}{*}{$\begin{array}{l}\text { Customer } \\
\text { orientation }\end{array}$} & Service orientation & 0.73 & $\ldots \ldots$ & 0.73 \\
\hline & Quality of service & 0.23 & 0.42 & 0.65 \\
\hline & Customer satisfaction & 0.12 & 0.48 & 0.60 \\
\hline & Customer loyalty & 0.11 & 0.52 & 0.63 \\
\hline \multirow{3}{*}{$\begin{array}{l}\text { Service } \\
\text { orientation }\end{array}$} & Quality of service & 0.57 & & 0.57 \\
\hline & Customer satisfaction & 0.15 & 0.23 & 0.47 \\
\hline & Customer loyalty & 0.07 & 0.38 & 0.46 \\
\hline \multirow{2}{*}{$\begin{array}{l}\text { Quality of } \\
\text { service }\end{array}$} & Customer satisfaction & 0.57 & & 0.57 \\
\hline & Customer loyalty & 0.21 & 0.32 & 0.53 \\
\hline $\begin{array}{c}\text { Customer } \\
\text { loyalty }\end{array}$ & Customer loyalty & 0.56 & & 0.56 \\
\hline
\end{tabular}

Based on the above table, among the variables, customer orientation has the highest total effect $(0.73)$ on variableoriented service. The highest indirect effect related to variable customer orientation on customer loyalty with effect coefficient is 0.52 .

\section{Discussion and Conclusion}

Hypothesis 1: customer orientation of employees positively affects their service-oriented variable.

Standardized coefficient between the two variables was 0.73 . Coefficient between these two variables 21:19 (greater than 1.96) showed that this relationship is significant. This means that the customer orientation of employees to positively impact on their service-oriented. These results are in accordance with the results of Ming et al, (2013) and Jayavardna and Frle (2011), showed that customer orientation, service-oriented, service quality and perceived value on satisfaction and behavioral intentions positively affect on customers in the retail environment. 


\section{International Journal of Science and Research (IJSR) \\ ISSN (Online): 2319-7064 \\ Index Copernicus Value (2013): 6.14 | Impact Factor (2014): 5.611}

Hypothesis 2. The customer orientation of employees positively affects the quality of service perceived by the customer. Standardized coefficient between the two variables was 0.23 . Coefficient between these two variables 4, 60 (greater than 1.96) showed that this relationship is significant. This means that the customer orientation of employees to positively impact on customer perceived service quality. These results are in accordance with the results of Venus and Safaeeian (2014), Ming et al, (2013) and Jayavardna and Frle (2011), showed that customer orientation positively correlation with customer perceived service quality.

Hypothesis 3. The customer orientation of employees positively impact on customer satisfaction.

Standardized coefficient between the two variables was 0.12 . Coefficient between these two variables 2, 53 (greater than 1.96) showed that this relationship is significant. Therefore customer orientation of employees has a positive impact on customer satisfaction. These results are in accordance with the results of Venus and Safaeeian (2014) showed that from perspective of bank customers, most important factor in satisfaction is speed of service delivery. Ming et al, (2013), Jayavardna and Frle (2011) and HennigThurau (2004), showed that customer orientation, serviceoriented, service quality and perceived value on satisfaction and behavioral intentions positively affect on customers in the retail environment.

Hypothesis 4. The customer orientation of employees positively affects customer loyalty.

Standardized coefficient between the two variables was 0.11. Coefficient between these two variables 2, 76 (greater than 1.96) showed that this relationship is significant. Therefore customer orientation of employees has a positive impact on customer satisfaction. These results are in accordance with the results of Ming et al, (2013), Chiat et al. (2012), Sing and Koshi, (2012), Mikintash (2007) and Hennig-Thurau (2004).

Hypothesis 5. Service-oriented of employees positively influence the quality of service perceived by customers.

Standardized coefficient between the two variables was 0.57. Coefficient between these two variables 11, 4 (greater than 1.96) showed that this relationship is significant. Therefore service-oriented of employees positively influence the quality of service that perceived by customers. These results are in accordance with the results of Jayavardna and Frle (2011) and Liang et al, (2010).

Hypothesis 6. Service-oriented of employees has a positive impact on customer satisfaction.
Standardized coefficient between the two variables was 0.15 . Coefficient between these two variables 2, 74 (greater than 1.96) showed that this relationship is significant. Therefore service-oriented of employees has a positive impact on customer satisfaction. These results are in accordance with the results of Ming et al, (2014) and Jayavardna and Frle (2011).

Hypothesis 7. Service-oriented of employees positively affect customer loyalty.

Standardized coefficient between the two variables was 0.07 . Coefficient between these two variables 1, 54 (lower than 1.96) showed that this relationship is not significant. This means that hypothesis 1 rejected and the null hypothesis was confirmed, thus there are not service-oriented of employees positively affect customer loyalty. These results are in contrast with the results of Khaksartoudeh, (2013), Tiyab and Rajpour (2014), Ming etl al, (2013) and liang et al, (2010)

Hypothesis 8. Quality of service that perceived, positively impact on customer satisfaction.

Standardized coefficient between the two variables was 0.57 . Coefficient between these two variables 11, 56 (greater than 1.96) showed that this relationship is significant. Therefore quality of service that perceived, positively impact on customer satisfaction. These results are in accordance with the results of Moradi et al, (2011) and Jayavardna and Frle (2011).

Hypothesis 9. Quality of Service perceived positively affects customer loyalty.

Standardized coefficient between the two variables was 0.21 . Coefficient between these two variables 4, 53 (greater than 1.96) showed that this relationship is significant. Therefore quality of service perceived positively affects customer loyalty. These results are in accordance with the results of Khaksartoudeh (2013), Moradi et al, (2011), (2013), Tiyab and Rajpour (2014), Jayavardna and Frle (2011) and liang et al, (2010).

Hypothesis 10. Customer satisfaction has a positive impact on customer loyalty

Standardized coefficient between the two variables was 0.56 . Coefficient between these two variables 13, 36 (greater than 1.96) showed that this relationship is significant. Therefore customer satisfaction has a positive impact on customer loyalty. These results are in accordance with the results of Moradi et al, (2011), Shahpanah (2004), Singh, R. and Koshy (2011) and Hennig-Thurau (2004).

According to reject the hypothesis of 7 based on the effect of lack of service-oriented of employees on customer loyalty, final research model presented in the figure below. 


\section{International Journal of Science and Research (IJSR) ISSN (Online): 2319-7064}

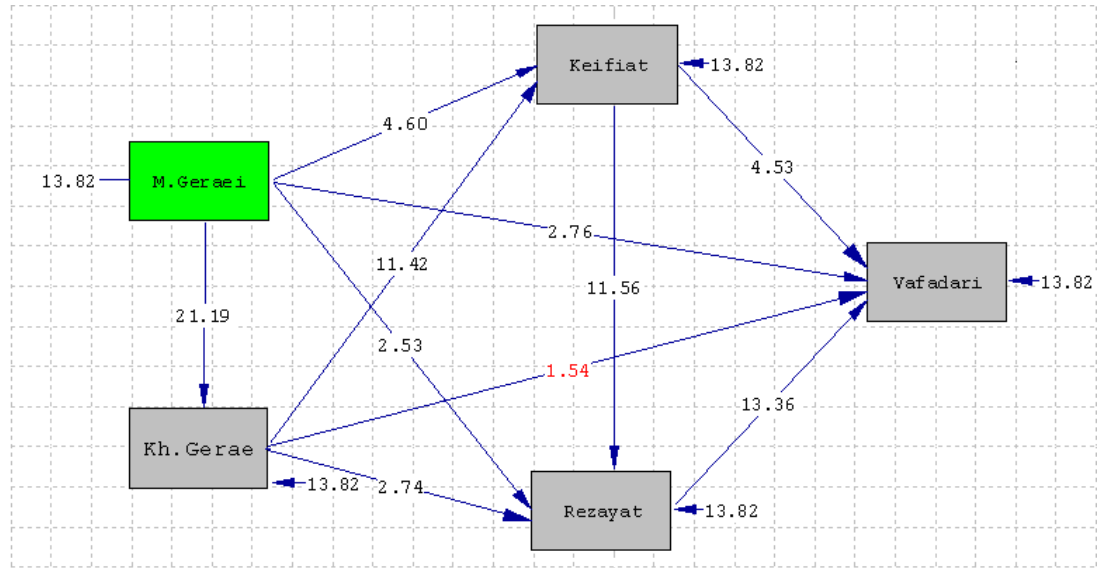

Figure 2: The path analysis model (a significant number)

Given the positive impact customer orientation on Serviceoriented of employees, service quality, customer satisfaction and loyalty, it is suggested to managers Hyperstar stores, by improving the customer orientation of their employees try to improve its positive consequences (such as service-oriented, service quality, customer satisfaction and loyalty). In this context, the following suggestions are offered. Intermittent and continuous training courses for staff to increase information, knowledge, expertise and technical competence. After hiring, professional skills jobs and desired behavior should also be trained to the staff. Training should encompass the entire period of working life to enable staff to respond to changes in technology and customer and job requirements.

This study, like any other scientific research faced with limitations, but researchers have devoted all their efforts that this limitation does not interfere with the proper conduct research and its results. Given that the results of the study is limited to the period of data collection and research, therefore have not generalization capability to other periods and carry out similar studies in future periods is necessary. Since the statistical population of the study is consumers of Hyperstar stores in Tehran, results of the study have not generalization capability to other stores, cities and countries. Therefore, recommended to the future researchers that perform similar research in other condition and investigate other positive outcomes of customer orientation and Service orientation.

\section{References}

[1] Hennig-Thurau, T.(2004). Customer orientation of service employees: Its impact on customer satisfaction, commitment, and retention", International Journal of Service Industry Management, Vol. 15, pp. 460-478.

[2] Javanmard, H. Soltanzadeh. A. (2010). Examination of online brands and websites and its impact on the trust and loyalty of customers (Case of cultural products through the Internet). Journal of Commerce, Issue 53, 256-225. (In Farsi)

[3] Jayawardhena, C. Farrell, A.M.(2011). Effects of retail employees' behaviours on customers' service evaluation. International Journal of Retail \& Distribution Management, Vol. 39, pp. 203-217.
[4] Liang, R.D. and Tseng, H.C. and Lee, Y.C.(2011) Impact of service orientation on frontline employee service performance and consumer response. International Journal of Marketing Studies, Vol. 2, pp. 67-74.

[5] Macintosh, G.(2007). Customer orientation, relationship quality, and relational benefits to the firm. Journal of Services Marketing, Vol. 21, pp. 150-159.

[6] Moradi. M. Mosavi. M Alimardani. B. (2011). Model for customer loyalty in the insurance industry (case study: an insurance company). Insurance Journal (insurance industry), No. 1, pp. 51-31. (In Farsi)

[7] Ming, I.E. Xu, A. Tan, Z. (2013). Exploring the impact of brand image on customer loyalty and commitment in China. Journal of Technology Management in China, Vol. 4, pp. 132-144.

[8] Oliver, R.L.(1999). Whence consumer loyalty. Journal of Marketing, Vol. 63 ,pp. 33-44.

[9] Sanayeii. A. Katayeb. S. Mortez pourhagh. H. (2006). Factors influencing customer preferences in selecting a TV using the analytic hierarchy process (Case Study: Isfahan). Faculty of Economy and Administrative Sciences, University of Isfahan, Issue 3, S57-41. (In Farsi)

[10] Seyed javadeyn. S. Keymasi. M. (2010). Quality management services. Tehran: publication of Negahe no.Second Edition. (In Farsi)

[11] Shahpanahi. A. (2004). Factors affecting customer loyalty and relationship marketing approach Saderat Bank of Iran in Tehran. Master's thesis, Islamic Azad University, Central Tehran Branch. (In Farsi)

[12] Singh, R. Koshy, R.(2011).A new conceptualization of salesperson's customer orientation: Propositions and implications. Marketing Intelligence \& Planning, Vol. 30, pp. 69-82.

[13] Venus. D. Safaeeian, M. (2014). Applied methods of marketing banking services to Iranian banks. Tehran: look at knowledge. (In Farsi) 